\title{
Biotransformation of nitrogen- and sulfur-containing pollutants during coking wastewater treatment: Correspondence of performance to microbial community functional structure
}

\author{
Dev Raj Joshi ${ }^{\text {a, b }}$, Yu Zhang ${ }^{\text {a, b, * }}$, Yinxin Gao ${ }^{\text {a, b }}$, Yuan Liu ${ }^{\text {a }}$, Min Yang a, b \\ a State Key Laboratory of Environmental Aquatic Chemistry, Research Center for Eco-Environmental Sciences, Chinese Academy of Sciences, Beijing, 100085, \\ China \\ b University of Chinese Academy of Sciences, Beijing, 100049, China
}

\section{A R T I C L E I N F O}

\section{Article history:}

Received 13 March 2017

Received in revised form

18 May 2017

Accepted 21 May 2017

Available online 24 May 2017

\section{Keywords:}

Coking wastewater

Nitrogen and sulfur containing organic

compound

Functional gene

Taxa-function relationship

Microbial network

\begin{abstract}
A B S T R A C T
Although coking wastewater is generally considered to contain high concentration of nitrogen- and sulfur-containing pollutants, the biotransformation processes of these compounds have not been well understood. Herein, a high throughput functional gene array (GeoChip 5.0) in combination with Illumina MiSeq sequencing of the 16S rRNA gene were used to identify microbial functional traits and their role in biotransformation of nitrogen- and sulfur-containing compounds in a bench-scale aerobic coking wastewater treatment system operated for 488 days. Biotransformation of nitrogen and sulfurcontaining pollutants deteriorated when $\mathrm{pH}$ of the bioreactor was increased to $>8.0$, and the microbial community functional structure was significantly associated with $\mathrm{pH}$ (Mantels test, $P<0.05$ ). The release of ammonia nitrogen and sulfate was correlated with both the taxonomic and functional microbial community structure $(P<0.05)$. Considering the abundance and correlation with the release of ammonia nitrogen and sulfate, aromatic dioxygenases (e.g. $x y l X Y, n a g G$ ), nitrilases (e.g. nhh, nitrilase), dibenzothiophene oxidase $(D b t A c)$, and thiocyanate hydrolase $(s c n A B C)$ were important functional genes for biotransformation of nitrogen- and sulfur-containing pollutants. Functional characterization of taxa and network analysis suggested that Burkholderiales, Actinomycetales, Rhizobiales, Pseudomonadales, and Hydrogenophiliales (Thiobacillus) were key functional taxa. Variance partitioning analysis showed that $\mathrm{pH}$ and influent ammonia nitrogen jointly explained $25.9 \%$ and $35.5 \%$ of variation in organic pollutant degrading genes and microbial community structure, respectively. This study revealed a linkage between microbial community functional structure and the likely biotransformation of nitrogen- and sulfurcontaining pollutants, along with a suitable range of $\mathrm{pH}(7.0-7.5)$ for stability of the biological system treating coking wastewater.
\end{abstract}

๑) 2017 Elsevier Ltd. All rights reserved.

\section{Introduction}

Coking wastewater is liquid waste from coke production laden with numerous pollutants, including phenols, polyaromatic hydrocarbons, nitrogen-, sulfur- and oxygen-containing heterocyclics, and acyclic compounds (Liu et al., 2017; Sharma and Philip, 2016; Zhang et al., 1998), and can induce toxic and carcinogenic impacts (Dehua et al., 2016; Zhao et al., 2014) on the environment.

\footnotetext{
* Corresponding author. State Key Laboratory of Environmental Aquatic Chemistry, Research Center for Eco-Environmental Sciences, Chinese Academy of Sciences, Beijing, 100085, China.
}

E-mail address: zhangyu@rcees.ac.cn (Y. Zhang).
Increasing environmental awareness coupled with more stringent standards has triggered various industries to challenge themselves in seeking appropriate wastewater treatment technologies (Teh et al., 2016).

Biological treatment of coking wastewater has long been of interest for environmental engineering studies. Most of the identified compounds, including phenols, thiocyanates, cyanides, and polyaromatic hydrocarbons, can be biologically removed (Bai et al., 2011; Jeong and Chung, 2006; Li et al., 2003). Recent pyrosequencing analysis has shown that microbial genera, such as Thiobacillus, Comamonas, Pseudomonas, Thaurea, Burkholderia, and Trichosporon, might play an important role in the degradation of phenols, thiocyanates, and cyanides in coking wastewater 
(Joshi et al., 2016; Ma et al., 2015a; Zhu et al., 2016). However, system performance instability or sudden failures of full-scale applications treating coking wastewater have also been reported (Kim et al., 2009; Vazquez et al., 2006b). The presence of toxic compounds like phenols and cyanides is often speculated as the main reason for the deterioration of treatment performance (Amor et al., 2005; Sharma and Philip, 2014). Judging from the high biodegradability of these pollutants (Feng et al., 2015; Marrot et al., 2006; Papadimitriou et al., 2009), however, it is assumed that some as yet unknown compounds might be more sensitive to environmental conditions and thus cause process failure.

On the other hand, excessive ammonium and sulfate can be generated during biological treatment of coking wastewater (Joshi et al., 2016; Staib and Lant, 2007; Vazquez et al., 2006a), suggesting possible biodegradation of nitrogen- and sulfur-containing organic and inorganic compounds. Based on the low chemical oxygen demand to total organic carbon (COD/TOC) ratio (Lim et al., 2003), refractory organic compounds including nitrogen- and sulfur-containing compounds (Huang et al., 2016; Zhang et al., 2013a), may represent a substantial fraction as only nitrogenous compounds constitute approximately $20-40 \%$ of the organic component in coking wastewater (Li et al., 2003; Meng et al., 2016). Indeed, nitrogen and sulfur-containing compounds are of great environmental importance due to their high toxicity and persistence (Dehua et al., 2016; Jensen et al., 2003) and hence might be critical for the treatment of coking wastewater. So understanding the functional ecology of biotransformation of these pollutants during the treatment process has great practical significance. Biodegradation of nitrogen and sulfur heterocycles via deamination and desulfurization pathways by several bacterial isolates including Pseudomonas, Burkholderia, Rhodococcus, Sphingomonas, Comamonas (Gai et al., 2007; Jiang et al., 2016; Tao et al., 2011) and thiocyanates via carbonyl pathway by Thiobacillus thioparus (Kim and Katayama, 2000; Watts and Moreau, 2016) are well studied. However, the knowledge on key microbial taxa and associated functional genes involved in the biotransformation of nitrogen and sulfur-containing pollutants in coking wastewater treatment system is still very limited. In addition, how environmental variables affect the biotransformation of these pollutants and influence the microbial community functional structure are not clearly understood. As an important environmental factor, $\mathrm{pH}$ has great impact on the biotransformation (Shen et al., 2015). Considering high concentration of ammonia in coking wastewater (Zhang et al., 2009), unionized free ammonia could be inhibitory to microbes. Since, $\mathrm{pH}$ equilibrates free ammonia and ammonium ion; it may be key factor to maintain the stability in a treatment system by controlling the equilibrium between free and ionized ammonia (Lay-Son and Drakides, 2008). However, effect of small shift of $\mathrm{pH}$ on microbial community functional structure and consequently, on biotransformation of nitrogen and sulfur pollutants have not yet been evaluated for coking wastewater treatment system.

In this study, a bench-scale activated sludge reactor was used to treat anaerobically pretreated coking wastewater over a period of 488 days, with a focus on the deamination and desulfurization processes. Except for the removal of COD and total phenols, parameters describing the release of ammonia and sulfate with respect to influent COD were used for the evaluation of wastewater treatment performance. Sludge samples from different temporal points during the operation period were taken for phylogenic and functional gene community analysis using Illumina MiSeq sequencing of 16S rRNA genes and functional gene microarray (GeoChip 5.0), respectively. GeoChip 5.0 contains 167,044 distinct probes, covering 395,894 coding sequences from 1593 functional gene families involved in microbial biogeochemical cycling and organic remediation (http://ieg.ou.edu/), and has been extensively employed to analyze the functional gene structure of microbial communities in different environments (Chan et al., 2013; Zhang et al., 2013b). The functional traits of abundant microbial taxa were identified by assigning taxa to functional gene categories involved in the degradation of organic pollutants, as described in GeoChip 5.0 (Chan et al., 2013). Potential bacterial hosts and functional genes associated with the biotransformation of organic pollutants, particularly those containing nitrogen or sulfur, were further explored by network analysis based on the GeoChip and MiSeq data. Lastly, the contributions of wastewater variables to the microbial community and functional structures were analyzed by variation partitioning analysis (VPA). This study could advance our understanding of biological treatment processes of coking wastewater, and improve the optimization of system operation.

\section{Materials and methods}

\subsection{Coking wastewater treatment and sludge sample collection}

Coking wastewater was obtained from a coking facility in Tangshan City, Hebei Province, China, and was treated using a bench-scale bioreactor consisting of anaerobic pretreatment and aerobic treatment (Joshi et al., 2016) for 488 days. The anaerobic pretreatment is described in the supplementary information (Experimental section 1). The aerobic bioreactor was operated with a constant hydraulic retention time (HRT) of $72 \mathrm{~h}$, dissolved oxygen (DO) of $2-4 \mathrm{mg} \mathrm{L}^{-1}$, and temperature of $20-25{ }^{\circ} \mathrm{C}$. The influent wastewater characteristics are given in supplementary information (Table S1). After 300 days, the $\mathrm{pH}(7.2 \pm 0.3)$ of the aerobic bioreactor was gradually increased up to 8.0 to 9.0 by addition of $0.1 \mathrm{M}$ $\mathrm{NaOH}$ solution (Chao et al., 2006).

Composite sludge samples were taken from the aerobic bioreactor at nine temporal points $(125,194,228,276,325,285,416,454$, and 484 days) and stored at $-80^{\circ} \mathrm{C}$ until DNA extraction. In parallel, grab samples of influent and effluent wastewater were collected. COD, TOC, total phenol, total nitrogen, ammonia nitrogen, and sulfate were measured as described previously (Joshi et al., 2016). Sample processing and analytical methods are given in the supplementary information (Experimental section 2). The release of ammonia nitrogen $\left(\mathrm{dNH}_{4}^{+}-\mathrm{N}\right)$ and sulfate $\left(\mathrm{dSO}_{4}^{2-}\right)$ with respect to influent COD was calculated as follows (1):

$d \mathrm{NH}_{4}^{+}-\mathrm{N} / \mathrm{COD}$ or, $\mathrm{dSO}_{4}^{2-} / \mathrm{COD}=\frac{\left[\text { Effluent concentration }\left(\mathrm{mg} \mathrm{L}^{-1}\right)-\text { Influent concentration }\left(\mathrm{mg} \mathrm{L}^{-1}\right) \text { of ammonia nitrogen }\left(\mathrm{NH}_{4}^{+}-\mathrm{N}\right) \text { or sulfate }\left(\mathrm{SO}{ }_{4}^{2-}\right)\right.}{\text { Influent concentration of COD }\left(\mathrm{mg} \mathrm{L}^{-1}\right)}$ 
Free ammonia was calculated as described previously (Anthonisen et al., 1976) using the following equation:
$20 \mathrm{~s}$, annealing at $53{ }^{\circ} \mathrm{C}$ for $25 \mathrm{~s}$, elongation at $68^{\circ} \mathrm{C}$ for $45 \mathrm{~s}$, and a final extension at $68{ }^{\circ} \mathrm{C}$ for $10 \mathrm{~min}$. Each sample was amplified in triplicate, and PCR products were pooled and purified using a

Free ammonia, $\mathrm{NH}\left(\mathrm{mg} \mathrm{L}^{-1}\right)=\frac{17}{14} \times \frac{\text { Total ammonia nitrogen }\left(\mathrm{mg} \mathrm{L}^{-1}\right) \times 10^{\mathrm{pH}}}{\mathrm{e}^{\left(6.344 / 273+{ }^{\circ} \mathrm{C}\right)}+10^{\mathrm{pH}}}$

\subsection{GeoChip 5.0 analysis}

Total community DNA for GeoChip analysis was extracted using a PowerSoil ${ }^{\circledR}$ DNA Isolation Kit (Mo Bio Laboratories, USA; Catalog no. 12888-100) (Supplementary Information experimental section $3)$. Each DNA sample was prepared by pooling independent extracts from three replicate sludge samples collected at different time (8.00 a.m., 1:00 p.m., 5:00 p.m.) of same day. DNA sample (2.0 $\mu \mathrm{g})$ was labeled using cyanine (Су3) dye with random primers and the Klenow fragment of DNA polymerase I (IMER Inc., USA), then purified (Qiagen QIAquick Kit, Germany) and dried using a SpeedVac at Vacuum Level 5.1 (ThermoSavent, USA) for $2 \mathrm{~h}$ at $45^{\circ} \mathrm{C}$ (Nostrand et al., 2016). The labeled DNA was re-suspended in hybridization buffer (Oligo aCGH Hybridization Kit, large, catalog number 5188-5380, Agilent Technologies Inc., USA) and denatured at $95{ }^{\circ} \mathrm{C}$ for $3 \mathrm{~min}$, with the array then hybridized at $67{ }^{\circ} \mathrm{C}$ for $24 \mathrm{~h}$ at a rotation speed of $20 \mathrm{rpm}$ in the chamber. The GeoChip 5.0 (Agilent Technologies Inc., USA) $180 \mathrm{k}$ array was applied for microarray hybridization. After hybridization, arrays were scanned with a SureScan Microarray Scanner (Agilent Technologies Inc., USA) in red and green channels (lasers with excitation wavelengths at 640 and $532 \mathrm{~nm}$, respectively), with $3 \mu \mathrm{m}$ resolution, 20-bit Tiff dynamic range ( $>105$ ), and $100 \%$ photomultiplier tube sensitivity for both channels. The raw data were extracted from the scanned images using the Feature Extraction program (Agilent Technologies Inc., CA, USA). GeoChip data normalization and quality filtering were performed as previously described (Nostrand et al., 2016), using the microarray data manager from the Institute for Environmental Genomics, University of Oklahoma (USA) (http://ieg.ou. edu/entrance.html). Before statistical analysis, logarithmic transformation $\left(\log _{10}\right)$ was performed, and the signals of all spots were transferred into relative abundances. All microarray hybridization data are available at the Institute for Environmental Genomics, University of Oklahoma (http://ieg.ou.edu).

\subsection{Illumina MiSeq sequencing}

Total DNA for Illumina MiSeq sequencing was extracted using the FastDNA ${ }^{\circledR}$ SPIN Kit for soil (Qbiogene, Solon, OH, USA) as described in supplementary information (experimental section 3 ). DNA extracts of replicate sludge samples were pooled together as mentioned in GeoChip analysis. The hyper-variable V4 region of the bacterial 16S rRNA gene was amplified using forward primer $515 \mathrm{~F}$ (5'-GTGCCAGCMGCCGCGGTAA-3') and reverse primer $806 \mathrm{R}$ (5'GGACTACHVGGGTTCTAAT- $3^{\prime}$ ) containing a variable 12 bp barcode sequence (Caporaso et al., 2012). Polymerase chain reaction (PCR) amplification was performed with $25 \mu \mathrm{L}$ of PCR mixture, constituting $0.1 \mu \mathrm{L}$ of AccuPrime High Fidelity Taq Polymerase, $1 \mu \mathrm{L}$ of each primer $(10 \mu \mathrm{M}), 2.5 \mu \mathrm{L}$ of $10 \times$ AccuPrime PCR buffer II (Invitrogen, USA), and $1 \mu \mathrm{L}$ of template DNA. A Veriti96-Well Thermal Cycler (Applied Biosystems, USA) was applied for amplification using the following thermal cycling conditions: initial predenaturation at $94{ }^{\circ} \mathrm{C}$ for $1 \mathrm{~min}, 35$ denaturation cycles at $94{ }^{\circ} \mathrm{C}$ for
QIAquick Gel Extraction Kit (Qiagen, Germany). Purified PCR products were quantified with PicoGreen. The purified mixture was diluted and denatured to obtain a sample DNA library, as described in the MiSeq Reagent Kit Preparation Guide (Illumina, USA), and mixed with an equi-volume of $8 \mathrm{pM}$ PhiX (Illumina, San Diego, CA, USA). The DNA sample mixture was loaded with read 1, read 2, and index sequencing primers on a 300-cycle $(2 \times 150$ paired ends $)$ kit, and run on a MiSeq.

As raw sequences were obtained, primers and spacers were trimmed out. The paired-end reads were overlapped to assemble the V4 tag sequences using FLASH (Magoc and Salzberg, 2011). Low quality fragments and sequences shorter than 240 bp were removed. The chimeras were checked and filtered using UCHIME (Edgar et al., 2011). The OTUs were classified using UCLUST (Edgar, 2010) at a 97\% similarity level. Taxonomic assignment was performed using the RDP classifier (Cole et al., 2009) (COLE) (http:// rdp.cme.msu.edu). The raw sequencing data were submitted to the NCBI Sequence Read Archive (http://www.ncbi.nlm.nih.gov/ sra/) under accession numbers SRR4253894 to SRR4253902.

\subsection{Network analysis}

The possible co-occurrence between microbial taxa and organic pollutant degrading genes was examined by random correlation matrix-based microbial network analysis (Deng et al., 2012; Tian et al., 2016). The bacterial OTUs obtained by Illumina MiSeq sequencing were combined with functional genes obtained by GeoChip 5.0 across all nine samples. For constructing the network, 269 items (175 OTUs and 94 organic pollutant degrading genes) that existed in at least five samples were combined and a correlation matrix was created. A similarity matrix was then obtained by taking the absolute values of the correlation matrix. The most suitable lowest threshold (Deng et al., 2012) was selected to obtain the Poisson distribution of the calculated eigenvalues. Online analysis pipeline (http://ieg2.ou.edu/MENA) was used for network analysis, and Cytoscape 3.3.0 software (http://cytoscape.org/) was applied to visualize the network graph.

\subsection{Statistical analysis}

Prior to statistical analysis, wastewater quality (Table S1) and bioreactor performance (Table S2) variables were standardized by dividing the difference between the sample values and the mean value of all samples by the standard deviation. Microbial community diversity indices, that is, Shannon-Weiner $(\mathrm{H})$ and Simpson were calculated using R 3.2.5 (http://www.r-project.org/) with the vegan package. The relationships among microbial OTU and functional gene abundances with wastewater variables (influent wastewater, bioreactor performance, and $\mathrm{pH}$ ) were examined by Mantel tests.

Canonical correspondence analysis (CCA) was carried out to discern possible associations among the microbial (phylogenetic and functional) community and wastewater variables, and partial 


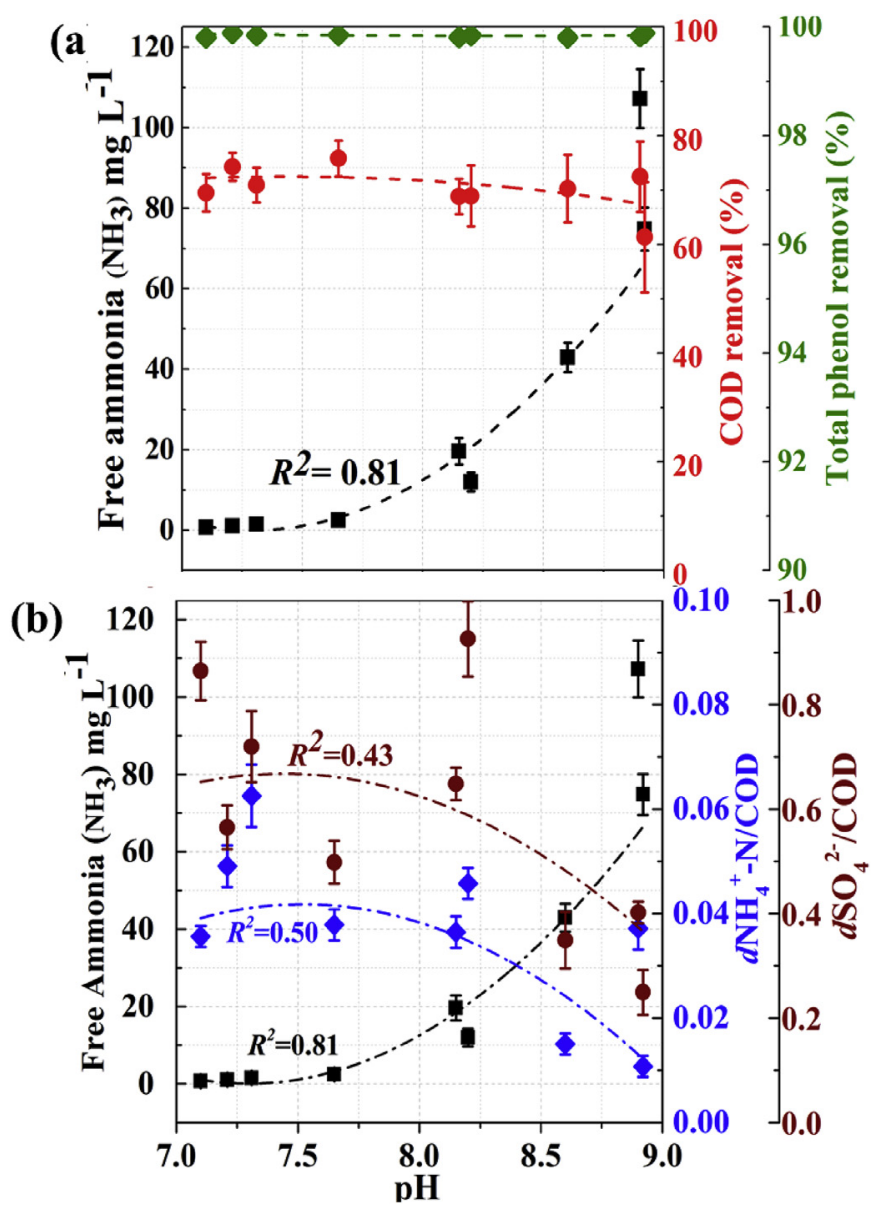

Fig. 1. Effect of pH and free ammonia ( $\mathbf{\square})$ on (a) total phenol ( $)$ and $\operatorname{COD}(\boldsymbol{0})$ removal efficiency, (b) release of ammonia nitrogen $\left(d \mathrm{NH}_{4}^{+}-\mathrm{N}\right)(\diamond)$ and sulfate $\left(d \mathrm{SO}_{4}^{2-}\right)(\mathbf{0})$ concentration with respect to influent COD during aerobic treatment. Dotted or dashed curve lines represent best possible polynomial curve fits.

CCA-based VPA was used to analyze the contributions of the wastewater variables in microbial community structures. Mantel tests, CCA, and partial CCA were performed using R 3.2.5 (http:// www.r-project.org/) with the vegan and stats packages. Significance tests were conducted by Monte Carlo permutation (999 times). P values $<0.05$ were regarded as significant.

\section{Results}

\subsection{Bioreactor performances}

Anaerobically pretreated coking wastewater with an average COD of $1978.8 \mathrm{mg} \mathrm{L}^{-1}$ (min. 1423.5 to max. 2817.0) (Table S1) was treated for 488 days by an aerobic bioreactor under constant operational conditions, except that the sludge $\mathrm{pH}$ was shifted from $7.2 \pm 0.3$ to $>8.0$ (up to 9.0 ) from 300 days onwards. As $\mathrm{pH}$ was increased, the average COD and TOC removal rates decreased from $72.6 \pm 2.5$ to $68.5 \pm 6.7 \%$ and $77.6 \pm 3.1$ to $72.6 \pm 5.3 \%$, respectively; however, total phenol removal was consistently high $(99.8 \pm 0.1 \%)$ across the operation period (Fig. 1a and Table S2). Overall average ammonia nitrogen and sulfate concentrations increased after aerobic treatment; however, the increase rate reduced from $235.6 \pm 36.7$ to $128.8 \pm 30.1 \%$ and $624.5 \pm 47.5$ to $311.5 \pm 37.2 \%$, respectively when $\mathrm{pH}$ was increased to $>8.0$ (Table S2). Our results indicated that the system was comparatively steady when $\mathrm{pH}$ was in a range of 7.1-7.6 (Fig. 1 and Table S2). The release of ammonia nitrogen $\left(d \mathrm{NH}_{4}^{+}-\mathrm{N} / \mathrm{COD}\right.$, range $\left.0.01-0.06\right)$ and sulfate $\left(d \mathrm{SO}_{4}^{2-} / \mathrm{COD}\right.$, range $0.25-0.93$ ) with respect to influent COD showed a characteristic decreasing pattern with increasing $\mathrm{pH}$ and free ammonia $\left(\mathrm{NH}_{3}\right)$, as fitted by following polynomial equations (Fig. 1b):

$$
\begin{aligned}
& \text { For } d \mathrm{NH}_{4}^{+}-\mathrm{N} / \mathrm{COD}\left(\mathrm{R}^{2}=0.50\right) ; \mathrm{y}=-0.009 \mathrm{x}^{2}+0.124 \mathrm{x}-0.396(3) \\
& \text { For } d \mathrm{SO}_{4}^{2-} / \mathrm{COD}\left(\mathrm{R}^{2}=0.43\right) ; \mathrm{y}=-0.209 \mathrm{x}^{2}+3.149 \mathrm{x}-11.13 \\
& \text { For } \mathrm{NH}_{3}\left(\mathrm{R}^{2}=0.81\right) ; \mathrm{y}=47.51 \mathrm{x}^{2}+714.9 \mathrm{x}+2685.8
\end{aligned}
$$

\subsection{Microbial phylogenetic community structure revealed by MiSeq sequencing}

Illumina MiSeq sequencing of the 16S rRNA gene revealed $10,582-19,610$ sequence reads with a total of 298 bacterial OTUs. Alpha diversity (Shannon-Weiner index) and percentage of unique bacterial OTUs ranged from 2.74 to 3.42 and 0.64 to 4.89 , respectively, among the samples (Table S3). In total, 16 phyla were obtained including Proteobacteria (58.95-87.75\%), Bacteroidetes (3.87-23.88\%), and Actinobacteria (0.98-3.70\%). At the genera level, unclassified genera belonging to order Burkholderiales (mostly Comamonadaceae) and Thiobacillus represented the major core community, accounting for $24.8-53.1 \%$ of total bacterial OTUs (Fig. S1).

The microbial community structure was correlated with wastewater quality and operational conditions (Table 1), revealing significant associations with influent ammonia nitrogen $(r=0.571$, $P=0.006)$, total nitrogen $(r=0.621, P=0.001)$, and $\mathrm{pH}(r=0.534$, $P=0.005)$. To discern the possible key functions of the bacterial community, correlation between bioreactor performance and phylogenetic community structure was also analyzed. The results revealed that the microbial community was significantly correlated in combined with the release of ammonia nitrogen $\left(d \mathrm{NH}_{4}^{+}-\mathrm{N} / \mathrm{COD}\right)$ and sulfate $\left(\mathrm{dSO}_{4}^{2-} / \mathrm{COD}\right)(r=0.535, P=0.002)$. However, no significant correlation was observed with COD or phenol removal efficiency.

\subsection{Microbial community functional structure and key functional genes revealed by GeoChip analysis}

The GeoChip-based microarray detected a total of 67,395 functional genes (1047 gene categories) from the nine samples, with alpha diversity (Shannon-Weiner index) ranging from 10.97 to 11.02 (Table S4). On average, 91.6\% of the functional genes were derived from bacteria, $2.4 \%$ from archaea, 5.2\% from eukaryote, and $0.9 \%$ from viruses. Bacterial functional genes were derived mainly from Proteobacteria (57.7\%), Actinobacteria (19.9\%), Firmicutes (8.2\%), Bacteroidetes (2.9\%), and Cyanobacteria (2.1\%).

In this study, functional genes involved in different biological processes, including nutrient carbon cycling (15.8\%), nitrogen cycling $(4.3 \%)$, sulfur cycling $(2.8 \%)$, organic pollutant removal $(8.8 \%)$, metal homeostasis $(26.6 \%)$, stress response (15.5\%), virulence $(15.5 \%)$, phosphorus cycling $(2.1 \%)$, and secondary metabolism (2.8\%), were detected (Fig. S2). Table S5 demonstrates the frequency distribution of functional genes involved in all bioprocesses. The nutrient cycling genes involved in carbon (10781 genes), nitrogen (2910 genes), sulfur (1950 genes), and phosphorus (1438 genes) cycling, including those involved in degradation of complex carbon compounds (e.g., amylase (amyA), chitinase, acetylglucosaminidase, cellobiase, arabinofuranosidase (ara), xylanase), ammonification (glutamate dehydrogenase $(g d h)$ and urease (ureC)), and sulfur/sulfide oxidation (sulfide-quinone reductase 
Table 1

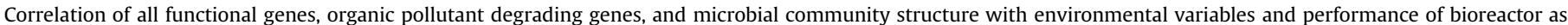
shown by Mantel test.

\begin{tabular}{|c|c|c|c|c|c|c|c|}
\hline & & \multicolumn{2}{|c|}{ All functional genes } & \multicolumn{2}{|c|}{$\begin{array}{l}\text { Organic pollutant } \\
\text { degrading genes }\end{array}$} & \multicolumn{2}{|c|}{ Microbial community } \\
\hline & & $r$ & $P$ & $r$ & $P$ & $r$ & $P$ \\
\hline \multirow[t]{5}{*}{ Wastewater quality } & COD & 0.023 & 0.416 & 0.112 & 0.281 & 0.209 & 0.108 \\
\hline & Total Phenol & -0.183 & 0.882 & -0.170 & 0.771 & -0.039 & 0.514 \\
\hline & Total nitrogen & 0.257 & 0.074 & 0.203 & 0.103 & 0.621 & 0.001 \\
\hline & Ammonia nitrogen & 0.253 & 0.078 & 0.172 & 0.150 & 0.571 & 0.006 \\
\hline & Sulfate & 0.023 & 0.434 & 0.142 & 0.213 & 0.442 & 0.016 \\
\hline Operational condition & $\mathrm{pH}$ & 0.31 & 0.038 & 0.319 & 0.040 & 0.534 & 0.005 \\
\hline \multirow[t]{3}{*}{ Performance of bioreactor } & COD removal & 0.072 & 0.289 & -0.167 & 0.749 & 0.059 & 0.310 \\
\hline & Total Phenol removal & -0.233 & 0.957 & -0.087 & 0.608 & -0.098 & 0.738 \\
\hline & $\begin{array}{l}d \mathrm{NH}_{4}^{+}-\mathrm{N} / \mathrm{COD} \\
d \mathrm{SO}_{4}^{2-} / \mathrm{COD}\end{array}$ & 0.456 & 0.004 & 0.489 & 0.002 & 0.535 & 0.002 \\
\hline
\end{tabular}

$r$ represents statistical correlation coefficient, $P$ represents $P$ value. Bold figures indicate significant correlation $(P<0.05)$.

(sqr), flavocytochrome sulfide dehydrogenase $(f c c A B)$, and sulfur oxidase (soxABCYV)), were detected.

A total of 5867 functional genes belonging to 99 gene families involved in organic pollutant removal (Table S5), degradation of aromatics (average relative abundance $6.3 \%$ of all genes), xenobiotic (herbicide related) compounds (1.1\%), chlorinated solvents $(1.1 \%)$, and other hydrocarbons $(0.43 \%)$ were detected. Most abundant aromatic degrading genes included intradiol ring-cleavage dioxygenase genes, catechol (0.58\%), one_ring_12diox (0.22\%), and mult_ring_12DiOx (0.19\%); xenobiotic related compound degrading gene, phn (0.41\%); chlorinated aromatic (containing amine) degrading gene, $t f d A$ (0.36\%); aromatic carboxylic acid degrading gene, nagG (0.36\%); BTEX (benzene, toluene, ethylbenzene, and xylene) compound degrading gene, catB $(0.2 \%)$; nitro-aromatics degradation genes, nitroreductase $(0.45 \%), n h h$, and $n s f A$ (each $0.25 \%$ ); and alkane monooxygenase, $\operatorname{alkB}(0.32 \%)$ (Fig. 2).

The Mantel test revealed that $\mathrm{pH}$ of the sludge was significantly correlated with the whole functional community structure $(r=0.31, P=0.038)$ and the organic pollutant degrading functional community structure $(r=0.319, P=0.040)$ (Table 1$)$. However, no significant correlation was observed between the whole functional community structures and influent wastewater quality $(P>0.05)$. Table S6 demonstrates correlation analysis between the

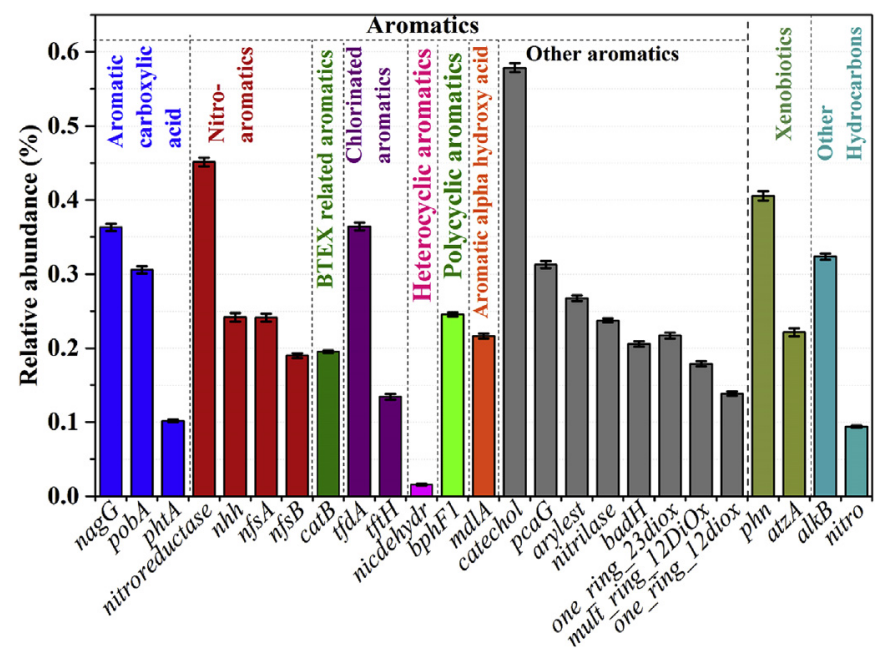

Fig. 2. Relative abundances of various organic pollutant degrading genes. The relative abundance was determined as percentage of the total signal intensities (normalized) of all genes detected by GeoChip 5.0. Data are presented as mean values from nine sludge samples and error bars represent standard deviation. abundances of individual gene families and wastewater variables and operational $\mathrm{pH}$ (of sludge). Majority of genes (18 families) correlated significantly with $\mathrm{pH}$ of the sludge. Apart from whole functional gene structure, 9 and 5 genes independently correlated with influent COD and influent ammonia nitrogen, respectively.

The possible association between microbial community functional genes and treatment performance was also evaluated by correlation analysis using Mantel tests. The organic pollutant degrading gene structure was strongly correlated with $d \mathrm{NH}_{4}^{+}-\mathrm{N} /$ COD and $d \mathrm{SO}_{4}^{2-} / \mathrm{COD}(r=0.489, P=0.002)$ (Table 1$)$, but was not significantly $(P>0.05)$ related to either COD or total phenol removal efficiencies. Furthermore, correlation analysis between the relative abundances of individual gene families (organic pollutant removal) and $d \mathrm{NH}_{4}^{+}-\mathrm{N} / \mathrm{COD}$ and $d \mathrm{SO}_{4}^{2-} / \mathrm{COD}$ revealed that 28 gene families (Table 2), which could cleave aromatic rings and degrade nitro- and heterocyclic-aromatics showed significant correlation. Strong correlation was demonstrated by toluate 1,2-dioxygenase, $x y l \mathrm{XY}(r=0.810, P=0.001)$; methylamine dehydrogenase, mau $A B$ $(r=0.649, P=0.001)$; salicylate hydroxylase, nagG $(r=0.469$, $P=0.004)$; cytochrome P450 monooxygenase, p450aro, $(r=0.495$, $P=0.008)$; nitrile hydratase, $n h h(r=0.527, P=0.006)$; and cyanuric acid amidohydrolase, atzD $(r=0.539, P=0.004)$ with $d \mathrm{NH}_{4}^{+}-\mathrm{N} / \mathrm{COD}$ and $\mathrm{dSO}_{4}^{2-} / \mathrm{COD}$. Importantly, nitrogen-containing organics degrading genes nitroreductases ( $n f_{s} A / B$, nitroreductase) and aniline dioxygenases ( $t f d A, \operatorname{tdn} B$ ), and sulfur-containing heterocyclics degrading gene dibenzothiophene oxidase (DbtAc) were also significantly correlated $(P<0.05)$ with $d \mathrm{NH}_{4}^{+}-\mathrm{N} / \mathrm{COD}$ and $d \mathrm{SO}_{4}^{2-} / \mathrm{COD}$. Although thiocyanate hydrolase ( $\left.\operatorname{scn} A B C\right)$ was not directly correlated with $d \mathrm{NH}_{4}^{+}-\mathrm{N} / \mathrm{COD}$ and $d \mathrm{SO}_{4}^{2-} / \mathrm{COD}$, GeoChip analysis detected 23 of $s c n A B C$ genes (Fig. S3) which were mostly derived from Thiobacillus thioparus. Table S7 lists the most abundant hosts of the important organic compound degrading genes suggesting that bacteria belonging to genera Burkholderia, including others were important functional trait.

\subsection{Organic pollutant degrading microbial taxa revealed by taxa- function and network analyses}

Functional traits of abundant microbial taxa were identified by assigning taxa to the functional gene categories involved in the degradation of organic pollutants (Chan et al., 2013). Results revealed the presence of genes indicating organic pollutant removal in 25 phyla, mostly bacterial ones. Among them, 18, 14, 13, 6 , and 16 phyla contained genes for degrading nitro-aromatic compounds, aromatic carboxylic acids, BTEX related compounds, chlorinated aromatics, and other hydrocarbons, respectively. Since most functional genes derived from Alphaproteobacteria, 
Table 2

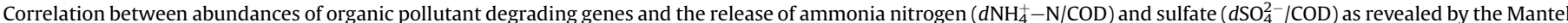
test $(P<0.05)$.

\begin{tabular}{|c|c|c|c|c|}
\hline Substrate & Enzyme & Genes & $r$ & $P$ \\
\hline \multirow[t]{3}{*}{ Aromatic carboxylic acid } & Benzoyl-CoA reductase, subunit A & $b c o$ & 0.581 & 0.002 \\
\hline & Salicylate hydroxylase & $\operatorname{nagG}$ & 0.469 & 0.004 \\
\hline & Toluate 1,2-dioxygenase subunit- $\alpha$ & $x y l X Y$ & 0.810 & 0.001 \\
\hline \multirow[t]{7}{*}{ Aromatics } & Acylamide amidohydrolase & amiE & 0.371 & 0.042 \\
\hline & Catechol 1,2 dioxygenase & catechol & 0.378 & 0.023 \\
\hline & Nitrilase & Nitrilase $e^{*}$ & 0.279 & 0.07 \\
\hline & Aromatic 1,2-dioxygenase & one_ring_12diox & 0.367 & 0.038 \\
\hline & Protocatechuate 4,5 -dioxygenase & proO & 0.348 & 0.022 \\
\hline & Aniline dioxygenase & $\operatorname{tdn} B^{*}$ & 0.285 & 0.078 \\
\hline & 3-hydroxybenzoate 6-hydroxylase & $x \ln D$ & 0.358 & 0.036 \\
\hline \multirow[t]{3}{*}{ BTEX related aromatics } & Methane/phenol/toluene hydroxylase & tomA & 0.499 & 0.01 \\
\hline & Muconate cycloisomerase & catB & 0.411 & 0.016 \\
\hline & Cresol dehydrogenase & pchcf & 0.365 & 0.043 \\
\hline Chlorinated aromatics & Aniline dioxygenase & $t f d A$ & 0.382 & 0.032 \\
\hline Heterocyclic aromatics & Dibenzothiophene oxidase & DbtAc & 0.324 & 0.047 \\
\hline \multirow[t]{4}{*}{ Nitroaromatics } & Nitroreductase & $n f S A \_2$ & 0.345 & 0.033 \\
\hline & Nitroreductase & $n f s B \_2$ & 0.448 & 0.005 \\
\hline & Nitrile hydratase & $n h h$ & 0.527 & 0.006 \\
\hline & Nitroreductase & nitroreductase_1 & 0.349 & 0.034 \\
\hline Polycyclic aromatics & 2-oxo-4-hydroxypentanoate aldolase & bphF1 & 0.503 & 0.004 \\
\hline \multirow[t]{4}{*}{ Xenobiotic related Hydrocarbons } & Amidohydrolase & $\operatorname{trz} A$ & 0.417 & 0.012 \\
\hline & Hydroxydechloro atrazine ethylaminohydrolase & $a t z B$ & 0.383 & 0.037 \\
\hline & Cyanuric acid amidohydrolase & $a t z D$ & 0.539 & 0.004 \\
\hline & Methylamine dehydrogenase small subunit & $\operatorname{mau} A B$ & 0.649 & 0.001 \\
\hline Other hydrocarbons & Taurine dioxygenase & $s d s A$ & 0.516 & 0.001 \\
\hline Others & Cytochrome P450 monooxygenase & p450aro & 0.495 & 0.008 \\
\hline
\end{tabular}

$r$ represents statistical correlation coefficient.*Significance level, $P<0.1$.

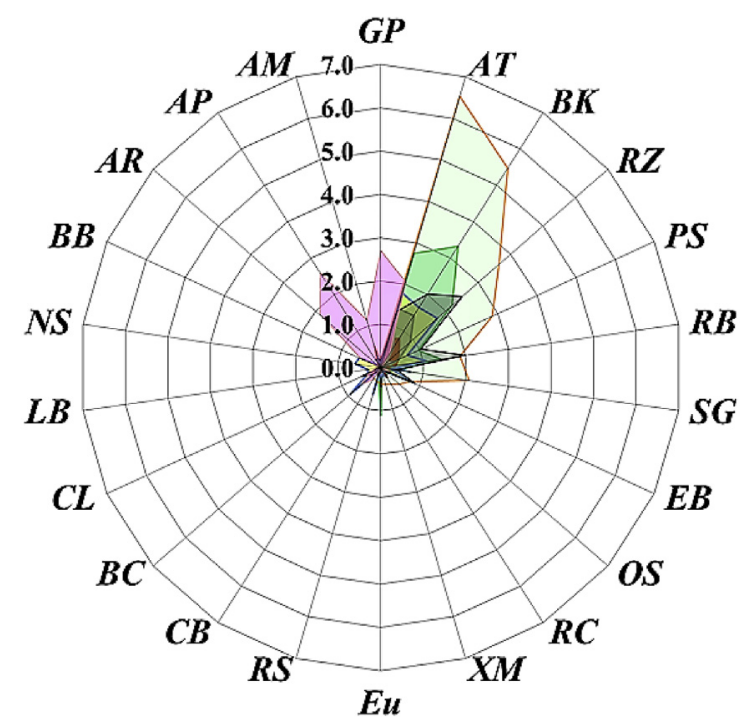

$\square$ Aromatic carboxylic acids

$\square$ Chlorinated aromatics

$\square$ Nitroaromatics

$\square$ BTEX related compounds

$\square$ Heterocyclic/ poly aromatics

$\square$ Other aromatics

$\square$ Xenobiotic related compounds $\square$ Other hydrocarbons

Fig. 3. Taxa-function relationships for organic pollutant degrading genes detected by GeoChip 5.0. Relative abundance was calculated as a percentage of normalized total signal intensities of gene categories derived from given taxa (order level) for each bioprocess. Mean values of relative abundances of all nine samples were plotted for the organic pollutant degrading functional genes. Abbreviation of microbial orders are: $A T=$ Actinomycetales, $B K=$ Burkholderiales, $R Z=$ Rhizobiales, $P S=$ Pseudomonadales, $S G=$ Sphingomonadales, $R B=$ Rhodobacterales, $E B=$ Enterobacteriales, $O S=$ Oceanospirillales, $R C=$ Rhodocyclales, $X M=$ Xanthomonadales, Eu $=$ Eurotiales, $R S=$ Rhodospirillales, $C B=$ Caulobacterales, $B C=$ Bacillales, $S D=$ Sordariales, $A P=$ Other Alphaproteobacteria, $A M=$ Alteromonadales, $A R=$ Aeromonadales, $G P=$ Other Gammaproteobacteria, $C L=$ Clostridiales, $L B=$ Lactobacillales, $N S=$ Neisseriales $B B=$ Bifidobacteriales
Betaproteobacteria, Gammaproteobacteria, Actinobacteria, and unclassified bacteria demonstrated the highest signal intensities for the degradation of organic pollutants (Fig. S4), we assigned taxafunction relationships at the order level (Fig. 3). We found that aromatic carboxylic acids and nitro-aromatic compound degrading genes were derived from Burkholderiales (relative abundance of genes $3.2 \%$ and $1.8 \%$, respectively) and Actinomycetales (2.9\% and $1.9 \%$, respectively), whereas xenobiotic compound degrading genes were abundant in Rhizobiales (2.3\%) and Rhodobacteriales (2.0\%). Other aromatic compound degrading genes were mostly contained in Actinomycetales (6.7\%), Burkholderiales (5.7\%), Rhizobiales (3.9\%), and Pseudomonadales (3.0\%). Other hydrocarbon (mostly aliphatic) degrading functional genes were found in unclassified Alphaproteobacteria (2.5\%), unclassified Gammaproteobacteria (2.8\%), and Aeromonadales (1.0\%).

The concurrences between taxa and functional genes, based on the hypothesis that the abundance pattern of genes is similar to that of the host taxa, were further verified using a RMT-based network approach (Deng et al., 2012). Fig. 4 visualizes the firstranked cluster of positive edges (links) connected among nodes of functional genes (GeoChip) and bacterial genera (Illumina MiSeq). The network analysis clearly showed that Proteobacteria (22 nodes) and Actinobacteria (7 nodes) were dominantly linked with functional genes (Table S8). Burkholderia (3 nodes) cooccurred with sulfur heterocyclic compound degrading gene, DbtAc (Dibenzothiophene oxidase), aromatic ring hydroxylating genes, pchcf (cresol hydroxylase), $x \ln D$, and mult_ring_12Diox, and nitrogen containing organics degrading gene, nitrilase (Fig. 4). Genera belonging to Alphaprobacteria viz. Rhizobium (1 node), Sphingobium (2 nodes), and Paracoccus (2 nodes) were also linked with functional genes involved in the degradation of similar compounds.

\subsection{Contribution of wastewater variables in shaping microbial community and functional gene structure}

Canonical correspondence analysis (CCA) was applied to 


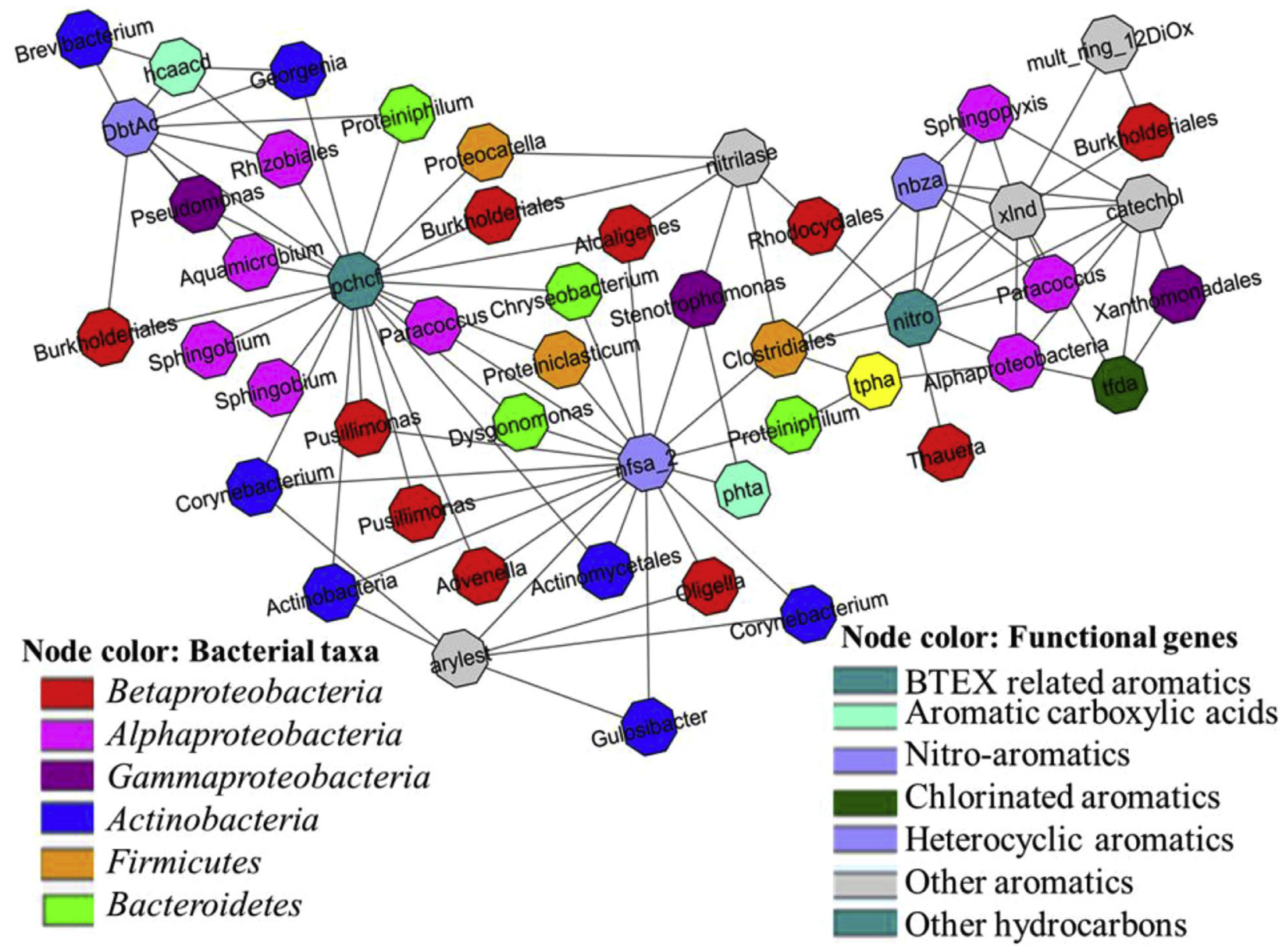

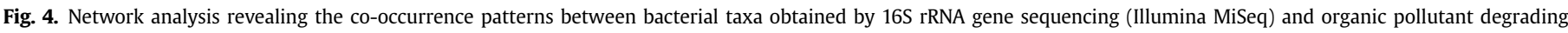

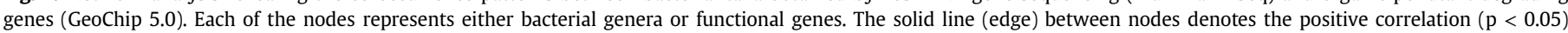
between the abundances of linked taxa and genes. Network was visualized by Cystoscape V3.3.0.

demonstrate the links between environmental variables and microbial community functional and phylogenetic structure. Based on automatic forward selection and variance inflation factors with 999 Monte Carlo permutations, four wastewater quality parameters (influent $\mathrm{COD}$, total nitrogen, $\mathrm{NH}_{4}^{+}-\mathrm{N}$, and sulfate) and an operational parameter $(\mathrm{pH})$ were included in the CCA bi-plot $(\mathrm{P}<0.05)$ (Fig. S5). The first axis was negatively correlated with $\mathrm{COD}, \mathrm{pH}$, and $\mathrm{NH}_{4}^{+}-\mathrm{N}$ and the second axis was positively correlated with influent COD. Both axes combined explained $34.4 \%$ of organic pollutant degrading gene diversity (Fig. S5a). Contributions of $\mathrm{COD}(\mathrm{C}), \mathrm{NH}_{4}^{+}-\mathrm{N}(\mathrm{N})$, and $\mathrm{pH}(\mathrm{P})$ on organic pollutant degrading functional structure and phylogenetic microbial community structure were estimated by VPA. A total of $43.9 \%$ and $56.9 \%$ of the variation in organic pollutant degrading genes and phylogenetic microbial community diversity, respectively (Fig. 5), were explained by three environmental variables $(p<0.05)$. Influent $\mathrm{COD}, \mathrm{NH}_{4}^{+}-\mathrm{N}$, and $\mathrm{pH}$ independently explained 16.96, 10.30 , and $10.69 \%$ of total variations observed in organic pollutant degrading genes, and $16.5,10.34$, and $10.17 \%$ of total variations in the phylogenetic microbial community, respectively. Notably, combined $\mathrm{NH}_{4}^{+}-\mathrm{N}$ and $\mathrm{pH}$ explained $25.9 \%$ and $35.5 \%$ of variation of organic pollutant degrading genes and the phylogenetic microbial community, respectively (Fig. 5). Similar results were obtained by VPA of the variation in the whole microbial functional gene structure by the same variables (Fig. S6).

\section{Discussion}

Coking wastewater has variety of organic and inorganic pollutants, most of which are very toxic and harmful to human health and environment (Dehua et al., 2016). For instance, PAHs including heterocyclic compounds are known carcinogens (Zhang et al., 2013a), while many other pollutants including phenols and cyanides could inhibit microbial processes like nitrification (Li et al., 2010). Treatment technology and process operation have been studied for quite a long time, but limited advancement were achieved (Pal and Kumar 2014). Because of the significant presence and environmental consequences of the nitrogen- and sulfurcontaining pollutants, understanding their biotransformation during treatment process has important practical implications for harmless disposal of coking wastewater. Herein, we applied high throughput molecular methods to investigate a linkage between possible biotransformation of nitrogen- and sulfur-containing pollutants with microbial community functional structure in coking wastewater treatment system.

In this study, gradual increase in $\mathrm{pH}$ from 8.0 to 9.0 , reduced the release of ammonia nitrogen $\left(d \mathrm{NH}_{4}^{+}-\mathrm{N} / \mathrm{COD}\right)$ and sulfate $\left(d \mathrm{SO}_{4}^{2-}\right)$ COD) (Fig. 1), suggesting that the transformation of nitrogen- and sulfur-containing pollutants is one of the key factors in the biological treatment of coking wastewater. Normally, $\mathrm{pH}$ range of 6.5-8.5 is acceptable for biological treatment of wastewaters (Eckenfelder, 2000); however, in this study we found that 
(a)
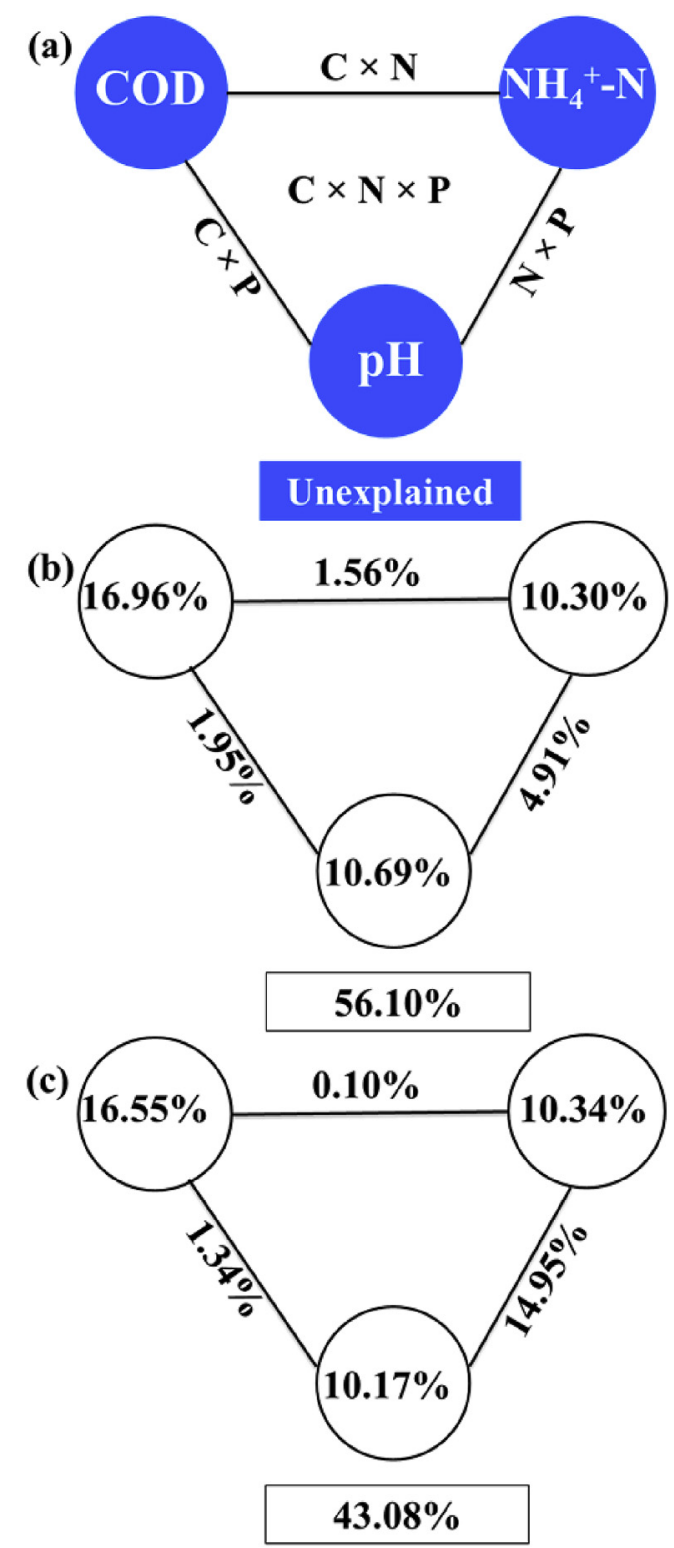

Fig. 5. Variation partitioning analysis of microbial diversity explained by influent COD (C), influent $\mathrm{NH}_{4}^{+}-\mathrm{N}(\mathrm{N})$, and $\mathrm{pH}(\mathrm{P})$ : (a) general outline, (b) all organic pollutant degrading genes as obtained from GeoChip 5.0 data, and (c) bacterial OTUs as obtained from Illumina MiSeq data. Each diagram represents the biological variation partitioned into the relative effects of each variable, in which geometric areas are proportional to the respective percentages of explained variation. Each node represents the variation explained by the respective variable alone. The edge represents the interaction between adjoining node variables.

$d \mathrm{NH}_{4}^{+}-\mathrm{N} / \mathrm{COD}$ and $d \mathrm{SO}_{4}^{2-} / \mathrm{COD}$ decreased when $\mathrm{pH}$ increased to $>$ 8.0. In agreement to this result, Shen et al. also found that $\mathrm{pH}$ range of 7.0-8.0 was the most suitable for the degradation of petroleum hydrocarbons (Shen et al., 2015). As pH controls the equilibrium between free ammonia and ammonium ions, the toxicity caused by un-ionized ammonia (Lay-Son and Drakides, 2008) might be an important reason for deterioration of biotransformation of nitrogen and sulfur containing pollutants. Of note, the free ammonia concentration, in the bioreactor was drastically increased when $\mathrm{pH}$ was increased to $>8.0$ as 'free ammonia' is the function of $\mathrm{pH}$ and temperature (Anthonisen et al., 1976). Besides, increased free ammonia $\left(>2.0 \mathrm{mgL}^{-1}\right)$ inhibits the biodegradation of thiocyanate (Lay-Son and Drakides, 2008). This result indicated that free ammonia might have exerted toxic effect on microbial community and their functions during the treatment process. Consequently, we found that $\mathrm{pH}$ was significantly correlated with both the whole microbial community $(r=0.442, P=0.005)$ and organic pollutant degrading gene structure $(r=0.319, P=0.04)$ (Table 1, Fig. S6). In addition, $\mathrm{pH}$ in combination with influent ammonia nitrogen was the main factor in shaping the microbial community and functional gene structure (35.5 and $25.9 \%$ of variations, respectively) (Fig. 5). Our results clearly suggested that maintenance of the $\mathrm{pH}$ between 7.0 and 8.0 and reducing free ammonia below toxic level could be crucial for removing the nitrogen- and sulfur-containing pollutants in coking wastewater treatment system. However, in contrast, the removal of total phenol was consistently high throughout the operational period (Fig. 1). This might be attributed to certain phenol degrading bacteria which may tolerate slight $\mathrm{pH}$ shift towards alkaline condition (Gallizia et al., 2003).

We observed a significant correlation of combined $d \mathrm{NH}_{4}^{+}-\mathrm{N} /$ $\mathrm{COD}$ and $d \mathrm{SO}_{4}^{2-} / \mathrm{COD}$ with taxonomic microbial community $(r=0.535, P=0.002)$, organic pollutant degrading genes $(r=0.489$, $P=0.002$ ) (Table 1 ) and individual gene families having potential to cleave broad spectrum aromatic rings including heterocyclic aromatics (Table 2). BTEX-related compound degrading dioxygenase genes, for instance, xylXY, nagG, p450aro, catechol, catB, and one_ring_12diox (Table 2), might have expressed to the enzymes related to the peripheral or central pathways for degradation of aromatic pollutants, including PAHs (Sierra-Garcia et al., 2014; Suenaga et al., 2014). Since single aromatic ring hydroxylating dioxygenase enzyme may have a wide range of substrate specificity (Fuchs et al., 2011; Suenaga et al., 2009), these genes allow the degradation of multiple aromatic pollutants. Some functional genes including $n h h, a t z D, t f d A$, and $t d n B$, which are responsible for degrading nitrogen heterocycles (Fetzner, 1998; Suenaga et al., 2009), and dibenzothiophene oxidase gene (DbtAc) for oxidation of dibenzothiophene (Andreolli et al., 2011) were also correlated with $d \mathrm{NH}_{4}^{+}-\mathrm{N} / \mathrm{COD}$ and $d \mathrm{SO}_{4}^{2-} / \mathrm{COD}$. Additionally, detection of plenty of thiocyanate hydrolase $(\operatorname{scn} A B C)$ genes (Fig. S4) was indicative of their role in conversion of thiocyanate compounds into ammonia and sulfate (Kim and Katayama, 2000; Watts and Moreau, 2016) as previously we found $98.2 \%$ removal of thiocyanates during coking wastewater treatment (Joshi et al., 2016). However, there was no statistical correlation between abundances of $S c n A B C$ genes and $d \mathrm{NH}_{4}^{+}-\mathrm{N} / \mathrm{COD}$ and/or $d \mathrm{SO}_{4}^{2-} / \mathrm{COD}$. In overall, our results are suggestive that the above functional genes in the aerobic sludge were linked to the bioreactor performance, particularly to the biotransformation of nitrogen- and sulfur-containing pollutants possibly via deamination and desulfurization pathways.

Taxonomic diversity obtained from 16S rRNA gene sequencing (Fig. S1) of this study corroborated previous molecular surveys of coking wastewater treatment plants (Joshi et al., 2016; Ma et al., 2015a; Zhu et al., 2016), showing a unique differences from those commonly occurring in municipal wastewater treatment plants (Wang et al., 2012). Most abundant bacteria Comamonas and Thiobacillus along with Burkholderia are characteristics of phenolic wastewaters particularly, coking wastewater treatment sludge and are commonly appreciated for biodegradation of phenol, thiocyanate and various nitrogen- and sulfur-containing PAHs like carbazole, dibenzothiophene (Felföldi et al., 2010; Jiang et al., 2016; Ma et al., 2015b). However, direct relations between these taxa and their functions for removal of organic pollutants have not yet been clearly demonstrated in coking wastewater treatment systems.

In this study, taxa-function analysis revealed that majority of aromatic pollutants, including nitroaromatics, aromatic carboxylic acids, BTEX and xenobiotic related compounds could be degraded mainly by Burkholderiales, Actinomycetales, Rhizobiales, 
Pseudomonadales (Fig. 3). Liang et al. found that Actinobacteria (Rodococcus sp., Mycobacterium sp., Nocardioides sp., etc), Burkholderia sp., and Pseudomonas sp. most abundant members of PAHs degrading community in oil contaminated soil by GeoChip analysis (Liang et al., 2011). Previously, different isolated strains belonging to these taxa have been documented for their potential to degrade many of nitrogen-, sulfur- and oxygen-containing heterocyclic pollutants (Seo et al., 2009; Xu et al., 2006). This finding was further supported by network analysis based on combined data of 16s rRNA gene sequencing by Illumina Miseq and functional genes by GeoChip5.0, which showed a correlation based cooccurrence of mainly Proteobacteria and Actiobacteria with aromatic pollutant removal genes (Fig. 4). The positive edge between Burkholderia and DbtAC gene was specifically notable because this gene is actually derived from Burkholderia sp. DBT1 (Andreolli et al., 2011). While Thiobacillus (order Hydrogenophiliales) was not regarded as a key taxa in taxa-function analysis, its taxonomic abundance (Fig. S1) and high signal intensities of $\operatorname{scn} A B C$ gene (Fig. S4) should not be overlooked. So, Thiobacillus was also considered as important functional taxa in this study. The linkage between organic pollutant degrading genes with their phylogenetic identity revealed how these unique microbial communities assemble due to functional adaptation in coking wastewater sludge. This is particularly important because of existence of complex and toxic compounds, which may challenge the optimal growth of functionally important microorganisms and inhibit removal efficiency of pollutants during the treatment of coking wastewater.

Understanding the core functional taxa is valuable in upgrading a sound process and operational strategy for effective biological treatment of coking wastewater. So adoption of new strategies would be useful for the removal of pollutants with a focus on key functional taxa and their functional genes. Since organic pollutant degrading genes of Burkholderia, Actinomycetes, Pseudomaonas, Thiobacillus etc. were correlated with the likely transformation of nitrogen- and sulfur-containing compounds, it may be possible to fortify their role in the treatment process. At the same time, realizing the crucial impact of $\mathrm{pH}$ in the transformation of nitrogenand sulfur-ontaining pollutants, precise maintenance of $\mathrm{pH}$ may greatly contribute to achieve optimum bioreactor performance and the system stability during aerobic treatment of coking wastewater.

Given the high functional potential analyzed at the DNA level, it should be noted that the biotransformation potential might have been overestimated in this study. To validate the results from this study, additional in-depth analyses applying metatranscriptomic and metaproteomic tool are needed. Besides, $\mathrm{pH}$ and ammonia nitrogen in combination only explained $25.9 \%$ of functional gene variations, and therefore other important environmental variables should be further investigated.

\section{Conclusion}

The biotransformation of nitrogen- and sulfur-containing pollutants was linked with microbial community functional structure in a long run aerobic coking wastewater treatment bioreactor. Following specific conclusions were made from this study:

- The likely biotransformation of nitrogen- and sulfur-containing pollutants was decreased characteristically when $\mathrm{pH}$ of the bioreactor was increased to $>8.0$.

- The microbial community, functional structure and organic pollutant degrading genes were correlated (Mantel test, $P<0.05)$ with $\mathrm{pH}$.

- Considering their significant presence and correlation with the release of ammonia nitrogen and sulfate, aromatic dioxygenases (e.g. $x y l X Y, n a g G)$, nitrilases (e.g. nhh, nitrilase), dibenzothiophene oxidase $(D b t A c)$, and thiocyanate hydrolase ( $s c n A B C)$ were important functional genes for biotransformation of nitrogen- and sulfur-containing pollutants.

- Functional characterization revealed that Burkholderiales, Actinomycetales, Rhizobiales, Pseudomonadales, and Hydrogenophiliales (Thiobacillus) were key functional taxa for degradation of pollutants.

- The microbial community functional structure was significantly associated (Mantel test, $P<0.05$ ) with $\mathrm{pH}$. Two parameters, $\mathrm{pH}$ (7.0-9.0) and ammonia nitrogen jointly explained 25.9 and $35.5 \%$ of variations in organic pollutant degrading genes and microbial community structure, respectively.

\section{Acknowledgements}

This study was supported by the National Natural Scientific Foundation of China (21437005) and the State Hitech Research and Development Project of the Ministry of Science and Technology of the People's Republic of China (2012AA063401). This project was also supported by a special fund of the State Key Joint Laboratory of Environmental Simulation and Pollution Control (15L03ESPC).

\section{Appendix A. Supplementary data}

Supplementary data related to this article can be found at http:// dx.doi.org/10.1016/j.watres.2017.05.045.

\section{References}

Amor, L., Eiroa, M., Kennes, C., Veiga, M.C., 2005. Phenol biodegradation and its effect on the nitrification process. Water Res. 39 (13), 2915-2920. http:// dx.doi.org/10.1016/j.watres.2005.05.019.

Andreolli, M., Lampis, S., Zenaro, E., Salkinoja-Salonen, M., Vallini, G., 2011. Burkholderia fungorum DBT1: a promising bacterial strain for bioremediation of PAHs-contaminated soils. FEMS Microbiol. Lett. 319 (1), 11-18. http:// dx.doi.org/10.1111/j.1574-6968.2011.02259.x.

Anthonisen, A.C. Loehr, R.C., Prakasam, T.B.S., Srinath, E.G., 1976. Inhibition of nitrification by ammonia and nitrous acid. J. Water Pollut. Control Fed. 48 (5), 835-852. http://dx.doi.org/10.2307/25038971.

Bai, Y., Sun, Q., Sun, R., Wen, D., Tang, X., 2011. Bioaugmentation and adsorption treatment of coking wastewater containing pyridine and quinoline using zeolite-biological aerated filters. Environ. Sci. Technol. 45 (5), 1940-1948. http://dx.doi.org/10.1021/es103150v.

Caporaso, J.G., Lauber, C.L., Walters, W.A., Berg-Lyons, D., Huntley, J., Fierer, N., Owens, S.M., Betley, J., Fraser, L., Bauer, M., Gormley, N., Gilbert, J.A., Smith, G., Knight, R., 2012. Ultra-high-throughput microbial community analysis on the Illumina HiSeq and MiSeq platforms. ISME J. 6, 1621-1624. http://dx.doi.org/ 10.1038/ismej.2012.8.

Chan, Y., Nostrand, J.D.V., Zhou, J., Pointing, S.B., Farrell, R.L., 2013. Functional ecology of an Antarctic dry valley. PNAS 110 (22), 8990-8995. http://dx.doi.org/ 10.1073/pnas.1300643110.

Chao, Y.M., Tseng, I.C., Chang, J.S., 2006. Mechanism for sludge acidification in aerobic treatment of coking wastewater. J. Hazard. Mater. B137, 1781-1787. http://dx.doi.org/10.1016/j.jhazmat.2006.05.024.

Cole, J.R., Wang, Q., Cardenas, E., Fish, J., Chai, B., Farris, R.J., Kulam-SyedMohideen, A.S., McGarrell, D.M., Marsh, T., Garrity, G.M., Tiedje, J.M., 2009. The ribosomal database project: improved alignments and new tools for rRNA analysis. Nucleic Acids Res. 37, D141-D145. http://dx.doi.org/10.1093/nar/ gkn879.

Dehua, M., Cong, L., Xiaobiao, Z., Rui, L., Lujun, C., 2016. Acute toxicity and chemical evaluation of coking wastewater under biological and advanced physicochemical treatment processes. Environ. Sci. Pollut. Res. Int. 23 (18) 18343-18352. http://dx.doi.org/10.1007/s11356-016-6882-Z.

Deng, Y., Jiang, Y.H., Yang, Y., He, Z., Luo, F., Zhou, J., 2012. Molecular ecological network analyses. BMC Bioinforma. 13, 113. http://dx.doi.org/10.1186/14712105-13-113.

Eckenfelder, W.W., 2000. Industrial Water Pollution Control, third ed. McGraw-Hill Science/Engineering/Math, USA, pp. 246-247. ISBN-13: 978-0070393646.

Edgar, R.C., 2010. Search and clustering orders of magnitude faster than BLAST Bioinformatics 26 (19), 2460-2461. http://dx.doi.org/10.1093/bioinformatics/ btq461.

Edgar, R.C., Haas, B.J., Clemente, J.C., Quince, C., Knight, R., 2011. UCHIME improves sensitivity and speed of chimera detection. Bioinformatics 27 (16), 2194-2200. http://dx.doi.org/10.1093/bioinformatics/btr381.

Felföldi, T., Székely, A.J., Gorál, R., Barkács, K., Scheirich, G., András, J., Rácz, A. 
Márialigeti, K., 2010. Polyphasic bacterial community analysis of an aerobic activated sludge removing phenols and thiocyanate from coke plant effluent. Bioresour. Technol. 101 (10), 3406-3414. http://dx.doi.org/10.1016 j.biortech.2009.12.053.

Feng, C., Huang, L., Yu, H., Yi, X., Wei, C., 2015. Simultaneous phenol removal, nitrification and denitrification using microbial fuel cell technology. Water Res. 76, 160-170. http://dx.doi.org/10.1016/j.watres.2015.03.001.

Fetzner, S., 1998. Bacterial degradation of pyridine, indole, quinoline and their derivatives under different redox conditions. Appl. Microbiol. Biotech. 49, 237-250. http://dx.doi.org/10.1007/s002530051164.

Fuchs, G., Boll, M., Heider, J., 2011. Microbial degradation of aromatic compounds from one strategy to four. Nat. Rev. Microbiol. 9, 803-816. http://dx.doi.org/ $10.1038 /$ nrmicro2652.

Gai, Z., Yu, B., Li, L., Wang, Y., Ma, C., Feng, J., Deng, Z., Xu, P., 2007. Cometabolic degradation of dibenzofuran and dibenzothiophene by a newly isolated carbazole-degrading Sphingomonas sp. strain. Appl. Environ. Microbiol. 73 (9) 2832-2838. http://dx.doi.org/10.1128/AEM.02704-06.

Gallizia, I., McClean, S., Banat, I.M., 2003. Bacterial biodegradation of phenol and 2,4-dichlorophenol. J. Chem. Technol. Biotechnol. 78, 959-963. http:/ dx.doi.org/10.1002/jctb.890.

Huang, Y., Hou, X., Liu, S., Ni, J., 2016. Correspondence analysis of bio-refractory compounds degradation and microbiological community distribution in anaerobic filter for coking wastewater treatment. Chem. Eng. J. 304, 864-872. http://dx.doi.org/10.1016/j.cej.2016.05.142.

Jensen, A.M., Finster, K.W., Karlson, U., 2003. Degradation of carbazole, dibenzothiophene, and dibenzofuran at low temperature by Pseudomonas sp. strain C3211. Environ. Toxicol. Chem. 22 (4), 730-735. http://dx.doi.org/10.1002/ etc. 5620220408

Jeong, Y.S., Chung, J.S., 2006. Simultaneous removal of COD, thiocyanate, cyanide and nitrogen from coal process wastewater using fluidized biofilm process. Process Biochem. 41, 1141-1147. http://dx.doi.org/10.1016 j.procbio.2005.12.010.

Jiang, B., Tan, L., Ning, S., Shi, S., 2016. A novel integration system of magnetically immobilized cells and a pair of graphite plate-stainless iron mesh electrodes for the bioremediation of coking wastewater. Bioresour. Technol. 216, 684-690. http://dx.doi.org/10.1016/j.biortech.2016.06.009.

Joshi, D.R., Zhang, Y., Tian, Z., Gao, Y., Yang, M., 2016. Performance and microbial community composition in a long-term sequential anaerobic-aerobic bioreacto operation treating coking wastewater. Appl. Microbiol. Biotechnol. 100 (18), 8191-8202. http://dx.doi.org/10.1007/s00253-016-7591-8.

Kim, S.J., Katayama, Y., 2000. Effect of growth conditions on thiocyanate degradation and emission of carbonyl sulfide by Thiobacillus thioparus THI115. Water Res. 34 (11), 2887-2894. http://dx.doi.org/10.1016/S0043-1354(00)00046-4.

Kim, Y.M., Park, D., Lee, D.S., Jung, K.A., Park, J.M., 2009. Sudden failure of biologica nitrogen and carbon removal in the full-scale pre-denitrification process treating cokes wastewater. Bioresour. Technol. 100 (19), 4340-4347. http:// dx.doi.org/10.1016/j.biortech.2009.04.014.

Lay-Son, M., Drakides, C., 2008. New approach to optimize operational conditions for the biological treatment of a high-strength thiocyanate and ammonium waste: pH as key factor. Water Res. 42 (3), 774-780. http://dx.doi.org/10.1016 j.watres.2007.08.009.

Li, H.B., Cao, H.B., Li, Y.P., Zhang, Y., Liu, H.R., 2010. Effect of organic compounds on nitrite accumulation during the nitrification process for coking wastewater Water Sci. Technol. 62 (9), 2096-2105. http://dx.doi.org/10.2166/wst.2010.371.

Li, Y.M., Gu, G.W., Zhao, J.F., Yu, H.Q., Qiu, Y.L., Peng, Y.Z., 2003. Treatment of cokeplant wastewater by biofilm systems for removal of organic compounds and nitrogen. Chemosphere 52, 997-1005. http://dx.doi.org/10.1016/S0045 6535(03)00287-X

Liang, Y., Van Nostrand, J.D., Deng, Y., He, Z., Wu, L., Zhang, X., Li, G., Zhou, J., 2011. Functional gene diversity of soil microbial communities from five oilcontaminated fields in China. ISME J. 5 (3), 403-413. http://dx.doi.org/ 10.1038/ismej.2010.142.

Lim, B.R., Hu, H.Y., Fujie, K., 2003. Biological degradation and chemical oxidation characteristics of coke-oven wastewater. Water Air Soil Pollut. 146 (1), 23-33. http://dx.doi.org/10.1023/A:1023923409422.

Liu, Y., Liu, J., Zhang, A., Liu, Z., 2017. Treatment effects and genotoxicity relevance of the toxic organic pollutants in semi-coking wastewater by combined treatment process. Environ. Pollut. 220 (A), 13-19. http://dx.doi.org/10.1016 j.envpol.2016.04.095.

Ma, Q., Qu, Y., Shen, W., Zhang, Z., Wang, J., Liu, Z., Li, D., Li, H., Zhou, J., 2015a. Bacterial community compositions of coking wastewater treatment plants in steel industry revealed by Illumina high-throughput sequencing. Bioresour. Technol. 179, 8. http://dx.doi.org/10.1016/j.biortech.2014.12.041.

Ma, Q., Qu, Y., Zhang, X., Liu, Z., Li, H., Zhang, Z., Wang, J., Shen, W., Zhou, J., 2015b. Systematic investigation and microbial community profile of indole degradation processes in two aerobic activated sludge systems. Sci. Rep. 5, 17674. http:/ dx.doi.org/10.1038/srep17674.

Magoc, T., Salzberg, S.L., 2011. FLASH: fast length adjustment of short reads to improve genome assemblies. Bioinformatics 27 (21), 2957-2963. http:/ dx.doi.org/10.1093/bioinformatics/btr507.

Marrot, B., Barrios-Martinez, A., Moulin, P., Roche, N., 2006. Biodegradation of high phenol concentration by activated sludge in an immersed membrane bioreactor. Biochem. Eng. J. (2006) 30, 174-183. http://dx.doi.org/10.1016 j.bej.2006.03.006.

Meng, X., Li, H., Sheng, Y., Cao, H., Zhang, Y., 2016. Analysis of a diverse bacteria community and degradation of organic compounds in a bioprocess for coking wastewater treatment. Desalination Water Treat. 57 (41), 19096-19105. http:/ dx.doi.org/10.1080/19443994.2015.1100556.

Nostrand, J.D.V., Yin, H., Wu, L., Yuan, T., Zhou, J., 2016. In: Martin, F., Uroz, S. (Eds.), Hybridization of Environmental Microbial Community Nucleic Acids by GeoChip. Springer Science+Business Media, Newyork, pp. 183-196. http:// dx.doi.org/10.1007/978-1-4939-3369-3_11.

Pal, P., Kumar, R., 2014. Treatment of coke wastewater: a critical review for developing sustainable management strategies. Sep. Purif. Rev. 43 (2), 89-123. http://dx.doi.org/10.1080/15422119.2012.717161.

Papadimitriou, C.A., Samaras, P., Sakellaropoulos, G.P., 2009. Comparative study of phenol and cyanide containing wastewater in CSTR and SBR activated sludge reactors. Bioresour. Technol. 100, 31-37. http://dx.doi.org/10.1016/ j.biortech.2008.06.004

Seo, J.S., Keum, Y.S., Li, Q.X., 2009. Bacterial degradation of aromatic compounds. Int J. Environ. Res. Public Health 6 (1), 278-309. http://dx.doi.org/10.3390/ ijerph6010278.

Sharma, N.K., Philip, L., 2014. Effect of cyanide on phenolics and aromatic hydrocarbons biodegradation under anaerobic and anoxic conditions. Chem. Eng. J. 256, 255-267. http://dx.doi.org/10.1016/j.cej.2014.06.070.

Sharma, N.K., Philip, L., 2016. Combined biological and photocatalytic treatment of real coke oven wastewater. Chem. Eng. J. 295, 20-28. http://dx.doi.org/10.1016/ j.cej.2016.03.031.

Shen, T., Pi, Y., Bao, M., Xu, N., Li, Y., Lu, J., 2015. Biodegradation of different petroleum hydrocarbons by free and immobilized microbial consortia. Environ. Sci. Process. Impacts 17 (12), 2022-2033. http://dx.doi.org/10.1039/ C5EM00318K.

Sierra-Garcia, I.N., Correa Alvarez, J., de Vasconcellos, S.P., Pereira de Souza, A., dos Santos Neto, E.V., de Oliveira, V.M., 2014. New hydrocarbon degradation pathways in the microbial metagenome from Brazilian petroleum reservoirs. PLoS One 9 (2), e90087. http://dx.doi.org/10.1371/journal.pone.0090087.

Staib, C., Lant, P., 2007. Thiocyanate degradation during activated sludge treatment of coke-ovens wastewater. Biochem. Eng. J. 34, 122-130. http://dx.doi.org/ 10.1016/j.bej.2006.11.029.

Suenaga, H., Koyama, Y., Miyakoshi, M., Miyazaki, R., Yano, H., Sota, M., Ohtsubo, Y., Tsuda, M., Miyazaki, K., 2009. Novel organization of aromatic degradation pathway genes in a microbial community as revealed by metagenomic analysis. ISME J. 3 (12), 1335-1348. http://dx.doi.org/10.1038/ismej.2009.76.

Suenaga, H., Mizuta, S., Miyazaki, K., Yaoi, K., 2014. Diversity of extradiol dioxygenases in aromatic-degrading microbial community explored using both culturedependent and culture-independent approaches. FEMS Microbiol. Ecol. 90, 367-379. http://dx.doi.org/10.1111/1574-6941.12390.

Tao, F., Zhao, P., Li, Q., Su, F., Yu, B., Ma, C., Tang, H., Tai, C., Wu, G., Xu, P., 2011. Genome sequence of Rhodococcus erythropolis XP, a biodesulfurizing bacterium with industrial potential. J. Bacteriol. 193 (22), 6422-6423. http://dx.doi.org/ 10.1128/JB.06154-11.

Teh, C.Y., Budiman, P.M., Shak, K.P.Y., Wu, T.Y., 2016. Recent advancement of coagulation-flocculation and its application in wastewater treatment. Ind. Eng. Chem. Res. 55 (16), 4363-4389. http://dx.doi.org/10.1021/acs.iecr.5b04703.

Tian, Z., Zhang, Y., Yu, B., Yang, M., 2016. Changes of resistome, mobilome and potential hosts of antibiotic resistance genes during the transformation of anaerobic digestion from mesophilic to thermophilic. Water Res. 98, 261-269. http://dx.doi.org/10.1016/j.watres.2016.04.031.

Vazquez, I., Rodriguez, J., Maranon, E., Castrillon, L., Fernandez, Y., 2006a. Simultaneous removal of phenol, ammonium and thiocyanate from coke wastewater by aerobic biodegradation. J. Hazard. Mater. 137 (3), 1773-1780. http:// dx.doi.org/10.1016/j.jhazmat.2006.05.018.

Vazquez, I., Rodriguez, J., Maranon, E., Castrillon, L., Fernandez, Y., 2006b. Study of the aerobic biodegradation of coke wastewater in a two and three-step activated sludge process. J. Hazard. Mater. 137 (3), 1681-1688. http://dx.doi.org/ 10.1016/j.jhazmat.2006.05.007.

Wang, X., Hu, M., Xia, Y., Wen, X., Ding, K., 2012. Pyrosequencing analysis of bacterial diversity in 14 wastewater treatment systems in China. Appl. Environ. Microbiol. 78 (19), 7042-7047. http://dx.doi.org/10.1128/AEM.01617-12.

Watts, M.P., Moreau, J.W., 2016. New insights into the genetic and metabolic diversity of thiocyanate-degrading microbial consortia. Appl. Microbiol. Biotechnol. 100 (3), 1101-1108. http://dx.doi.org/10.1007/s00253-015-7161-5.

Xu, P., Yu, B., Li, F.L., Cai, X.F., Ma, C.Q., 2006. Microbial degradation of sulfur, nitrogen and oxygen heterocycles. Trends Microbiol. 14 (9), 398-405. http:/ dx.doi.org/10.1016/j.tim.2006.07.002.

Zhang, M., Tay, J.H., Qian, Y., Gu, X.S., 1998. Coke plant wastewater treatment by fixed biofilm system for COD and $\mathrm{NH}_{3}-\mathrm{N}$ removal. Water Res. 32 (2), 519-527. http://dx.doi.org/10.1016/S0043-1354(97)00231-5.

Zhang, T., Ding, L., Ren, H., Xiong, X., 2009. Ammonium nitrogen removal from coking wastewater by chemical precipitation recycle technology. Water Res. 43 (20), 5209-5215. http://dx.doi.org/10.1016/j.watres.2009.08.054.

Zhang, W., Wei, C., Yan, B., Feng, C., Zhao, G., Lin, C., Yuan, M., Wu, C., Ren, Y., Hu, Y., 2013a. Identification and removal of polycyclic aromatic hydrocarbons in wastewater treatment processes from coke production plants. Environ. Sci. Pollut. Res. Int. 20 (9), 6418-6432. http://dx.doi.org/10.1007/s11356-013-1697-

Zhang, Y., Xie, J., Liu, M., Tian, Z., He, Z., van Nostrand, J.D., Ren, L., Zhou, J., Yang, M., 2013b. Microbial community functional structure in response to antibiotics in pharmaceutical wastewater treatment systems. Water Res. 47 (16), 6298-6308. http://dx.doi.org/10.1016/j.watres.2013.08.003. 
Zhao, J.L., Jiang, Y.X., Yan, B., Wei, C., Zhang, L.J., Ying, G.G., 2014. Multispecies acute toxicity evaluation of wastewaters from different treatment stages in a coking wastewater treatment plant. Environ. Toxicol. Chem. 33 (9), 1967-1975. http:// dx.doi.org/10.1002/etc.2638.
Zhu, S., Wu, H., Wei, C., Zhou, L., Xie, J., 2016. Contrasting microbial community composition and function perspective in sections of a full-scale coking wastewater treatment system. Appl. Microbiol. Biotechnol. 100 (2), 949-960. http:// dx.doi.org/10.1007/s00253-015-7009-z. 